\title{
Reproductive Output and Seasonality of Limnoperna fortunei
}

\author{
Demetrio Boltovskoy, Brian Morton, Nancy Correa, Daniel Cataldo, Cristina \\ Damborenea, Pablo E. Penchaszadeh and Francisco Sylvester
}

\begin{abstract}
Young Limnoperna fortunei mature sexually from 5-6 to $\sim 15 \mathrm{~mm}$. The species is generally dioecious, with approximately equal numbers of males and females and very small $(<0.6 \%)$ proportions of hermaphrodites. The gametogenic cycle has been described for both Asian and South American populations, recognizing between four and five reproductive phases. Gonadal cycles based on histological sections yielded somewhat dissimilar results for different areas. In Hong Kong, two yearly peaks in reproductive output were detected. In South America, mature sperm and ova have been recorded year round and several irregularly spaced spawning events have been observed, as well as more or less continuous breeding punctuated by peaks in spring and at the end of the summer. Reproductive studies based on changes in the abundance of larvae in the water column have been carried out in South America and in Japan. In tropical and subtropical South America, larval output is more or less continuous for 6-10 months of the year, often with a major peak in spring-early summer, and a smaller one in the late summer-autumn. In Japan, at considerably lower water temperatures, larval production is limited to 1-2 months centered around summer. Apparent disagreements between results based on histological data and on larval counts stem from the fact that while the latter integrate the reproductive output of extensive mussel beds dispersed over large areas, histological evidence pinpoints with high precision the ripening and spawning of isolated mussel clusters. Aside from water temperature, several other factors ( $\mathrm{pH}$, salinity, dissolved oxygen, suspended solids, chlorophyll a, flood-drought cycles) have been proposed as reproductive triggers, but actual associations have not been demonstrated. Peak larval densities can exceed 20,000 ind. $/ \mathrm{m}^{3}$, but, normally, values range around 6000 ind.$/ \mathrm{m}^{3}$, showing major fluctuations within short periods, as well as changes as a function of time elapsed post colonization, and availability of substrata suitable for adult occupation. Microcystin-producing cyanobacterial blooms can kill L. fortunei larvae.
\end{abstract}

D. Boltovskoy $(\varangle) \cdot$ D. Cataldo $\cdot$ F. Sylvester

Facultad de Ciencias Exactas y Naturales, Instituto de Ecología, Genética

y Evolución de Buenos Aires (IEGEBA), Universidad de Buenos

Aires-CONICET, Ciudad Universitaria, 1428 Buenos Aires, Argentina

e-mail: demetrio@ege.fcen.uba.ar

D. Boltovskoy $\cdot$ D. Cataldo

Museo Argentino de Ciencias Naturales 'Bernardino

Rivadavia'-CONICET, Buenos Aires, Argentina

(C) Springer International Publishing Switzerland 2015

D. Boltovskoy (ed.), Limnoperna fortunei, Invading Nature - Springer Series

in Invasion Ecology 10, DOI 10.1007/978-3-319-13494-9_5 
Keywords Limnoperna fortunei $\cdot$ Golden mussel • Reproduction · Seasonal cycles • Cohorts

\section{Introduction}

The reproductive cycle of Limnoperna fortunei is probably one of the most intensively studied aspects of the species' biology. This interest is partly due to the fact that reproduction is perceived as one of the main biological traits of organisms in general and, again partly, because being an important fouling nuisance in industrial installations, strategies for its mitigation and control depend largely on the time frame over which such infrastructures are vulnerable to infestation. This occurs through the settlement of its planktonic larvae and therefore coincides with periods when the animal is reproductively active.

Seasonality in the reproduction of $L$. fortunei has been investigated using different approaches: (1) assessment of gonadal maturation, often with the aid of histological thin sections, (2) studies of temporal changes in the density of the species larvae in the plankton, (3) analyses of recruitments onto either natural or artificial substrata, and (4) various combinations of the above (Table 1).

B. Morton

School of Biological Sciences, The University of Hong Kong,

Hong Kong SAR, China

e-mail: prof_bmorton@hotmail.co.uk

N. Correa

Servicio de Hidrografía Naval (Ministerio de Defensa), and Escuela de Ciencias del Mar (Instituto Universitario Naval),

Av. Montes de Oca 2124, 1271 Buenos Aires, Argentina

e-mail: ncorrea@hidro.gov.ar

D. Cataldo

e-mail: daniel@ege.fcen.uba.ar

C. Damborenea

División Zoología Invertebrados, Museo de La Plata,

Universidad Nacional de La Plata and CONICET, Paseo del Bosque s/n,

1900 La Plata, Argentina

e-mail: cdambor@fcnym.unlp.edu.ar

P. E. Penchaszadeh

Museo Argentino de Ciencias Naturales 'Bernardino Rivadavia'-CONICET,

Av. Angel Gallardo 470, 1405 Buenos Aires, Argentina

e-mail: pablop@retina.ar

F. Sylvester

Facultad de Ciencias Naturales,Instituto para el Estudio de la Biodiversidad de Invertebrados (IEBI), Universidad Nacional de Salta, Av. Bolivia 5150, 4400 Salta, Argentina e-mail: fsylvester@natura.unsa.edu.ar 


\begin{tabular}{|c|c|c|c|c|c|c|c|c|c|c|c|c|}
\hline 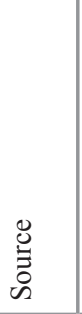 & 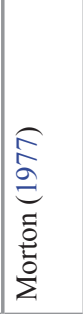 & 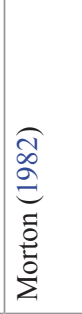 & 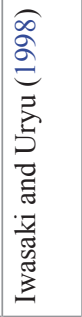 & 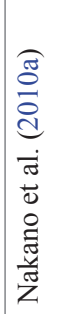 & 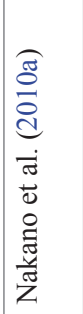 & 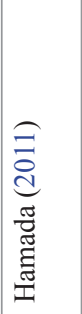 & 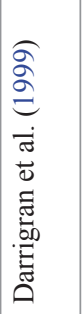 & 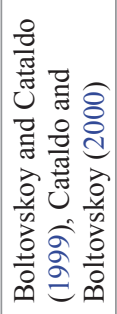 & 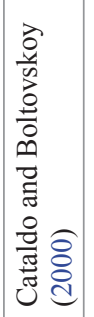 & 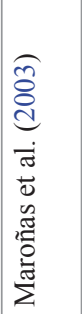 & 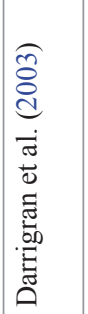 & 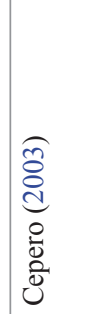 \\
\hline 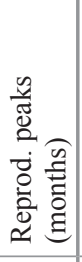 & 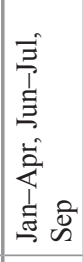 & 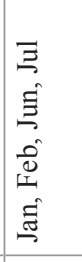 & $\begin{array}{l}0 \\
\infty \\
1 \\
\equiv \\
\Xi\end{array}$ & $\begin{array}{l}0 \\
0 \\
1 \\
\equiv \\
\Xi\end{array}$ & \begin{tabular}{l}
0 \\
0 \\
0 \\
00 \\
2 \\
\multirow{2}{4}{}
\end{tabular} & $\stackrel{00}{Z}$ & $\begin{array}{l}\overrightarrow{0} \\
0 \\
\overline{3} \\
\vdots \\
\vdots \\
\dot{z}\end{array}$ & $\begin{array}{l}0 \\
0 \\
01 \\
\vdots \\
z \\
z\end{array}$ & $\begin{array}{l}0 \\
0 \\
11 \\
1 \\
0 \\
0\end{array}$ & 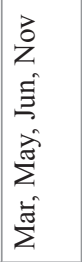 & $\begin{array}{l}3 \\
z \\
00 \\
00 \\
\vdots \\
\vdots \\
\Xi \\
\vdots \\
\text { Eే }\end{array}$ & $\begin{array}{l}\bar{c}_{2} \\
1 \\
0 \\
z \\
z\end{array}$ \\
\hline 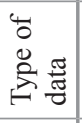 & $\simeq$ & $\circlearrowright$ & ه & - & - & ـ & $\simeq$ & $\simeq$ & -1 & $\simeq$ & 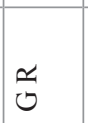 & \lrcorner \\
\hline 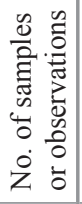 & $\stackrel{\infty}{\sim}$ & $\stackrel{\infty}{\sim}$ & $\simeq$ & $\hat{q}$ & gे & mे & $\stackrel{\sim}{ }$ & $\infty$ & 6 & $a$ & $\stackrel{0}{0}$ & $\stackrel{\sim}{\sim}$ \\
\hline 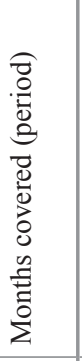 & 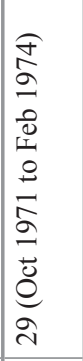 & 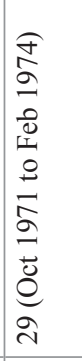 & 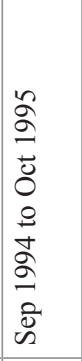 & 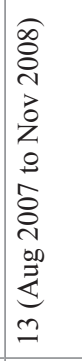 & 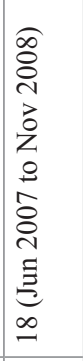 & 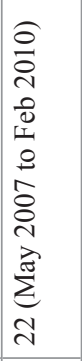 & 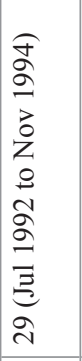 & 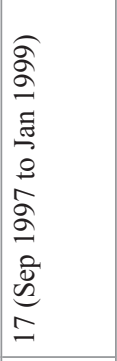 & 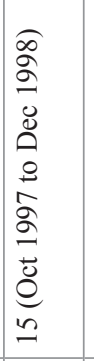 & 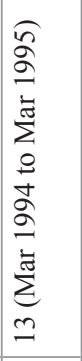 & 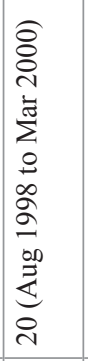 & 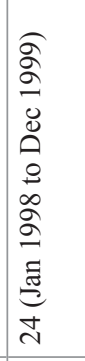 \\
\hline 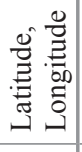 & 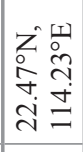 & 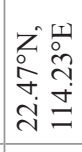 & 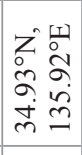 & 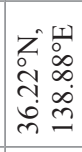 & 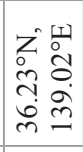 & 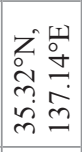 & 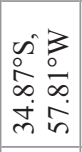 & $\begin{array}{ll}\dot{n} & 3 \\
0 & 0 \\
0 & \bar{\nu} \\
m & 0 \\
m & n\end{array}$ & $\begin{array}{ll}\tilde{n} & z \\
0 & 0 \\
0 & 0 \\
n & 7 \\
\dot{n} & 0 \\
m & n\end{array}$ & $\begin{array}{ll} & 0 \\
0 & 0 \\
0 & 0 \\
\infty & \infty \\
\dot{0} & 0 \\
m & i n\end{array}$ & 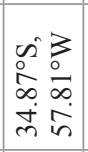 & 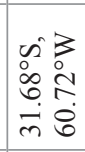 \\
\hline 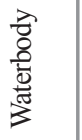 & 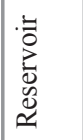 & 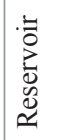 & : & 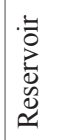 & 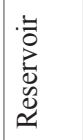 & : & 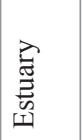 & $\stackrel{\overrightarrow{0}}{\vec{\alpha}}$ & 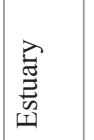 & $\begin{array}{c}\text { 志 } \\
\text { 䓌 } \\
\text { 品 }\end{array}$ & 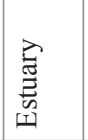 & $\stackrel{\vec{D}}{: \vec{z}}$ \\
\hline 巳્ల & 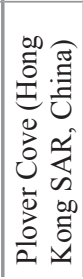 & 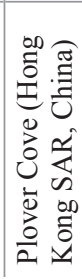 & 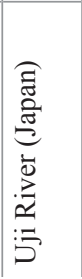 & 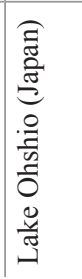 & 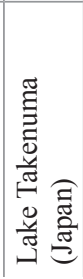 & 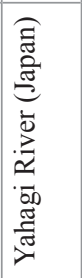 & 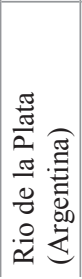 & 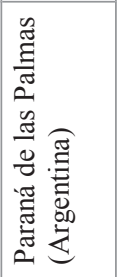 & 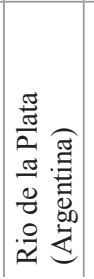 & 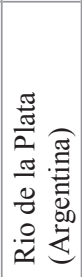 & 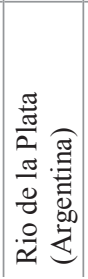 & 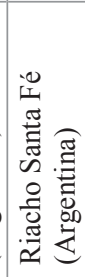 \\
\hline
\end{tabular}




\begin{tabular}{|c|c|c|c|c|c|c|c|c|c|c|c|c|c|}
\hline $\begin{array}{l}\stackrel{0}{0} \\
\stackrel{\Xi}{0} \\
\check{n}\end{array}$ & 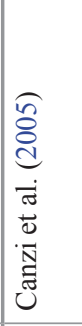 & 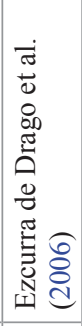 & 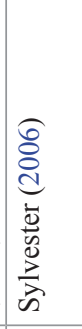 & 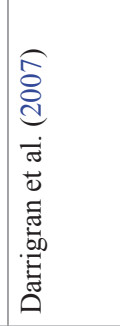 & 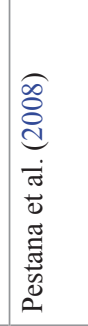 & 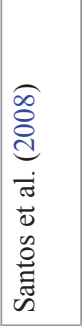 & 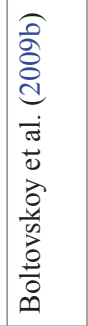 & 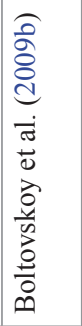 & 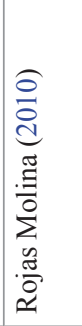 & 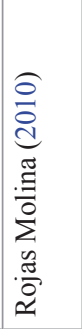 & 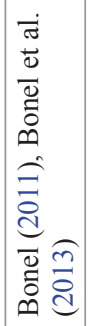 & 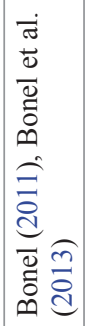 & 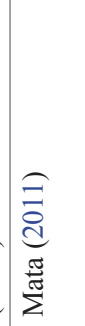 \\
\hline 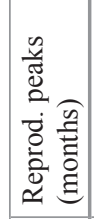 & 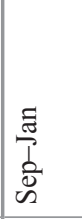 & $\begin{array}{l}\sum_{1}^{ \pm} \\
\text {ò } \\
\tilde{n}\end{array}$ & 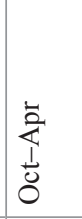 & $\begin{array}{l}0 \\
0 \\
11 \\
1 \\
0 \\
z\end{array}$ & 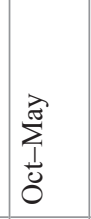 & 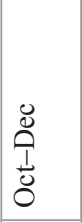 & $\begin{array}{l}\stackrel{a}{0} \\
\vdots \\
0 \\
0 \\
0\end{array}$ & $\begin{array}{l}\sum_{1}^{ \pm} \\
0 \\
0 \\
z\end{array}$ & $\begin{array}{l}\frac{\vec{c}}{4} \\
\frac{1}{0} \\
0\end{array}$ & $\begin{array}{l}\frac{1}{2} \\
\dot{1} \\
\frac{1}{0} \\
0\end{array}$ & $\sigma$ & $\sigma$ & 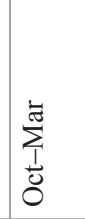 \\
\hline 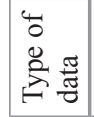 & لــ & בـ & ב & ك & - & ב & ـــ & لــ & لــ & ــ & ב & ك & 品 \\
\hline 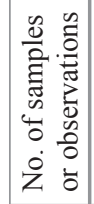 & 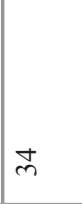 & $=$ & $\simeq$ & $\hat{\imath}$ & $\simeq$ & $\stackrel{\sim}{\sim}$ & in & ర్ & ষे & $\hat{m}$ & $\Xi$ & $\because$ & $\infty$ \\
\hline 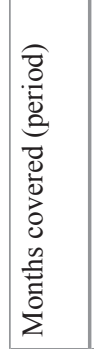 & 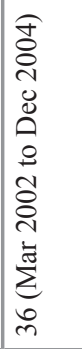 & 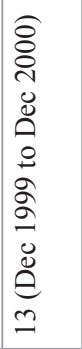 & 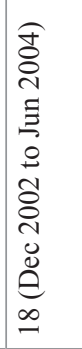 & 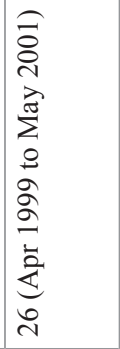 & 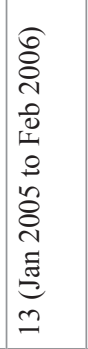 & 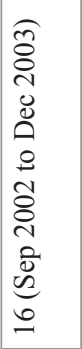 & 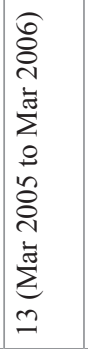 & 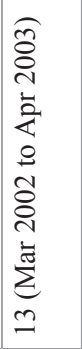 & 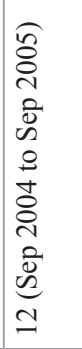 & 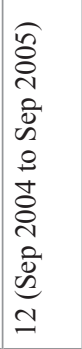 & 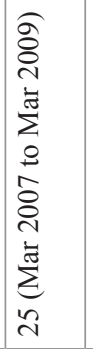 & 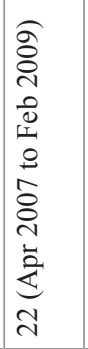 & 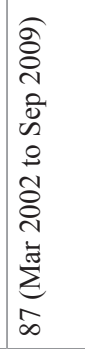 \\
\hline 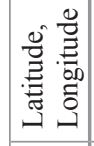 & 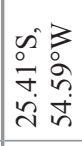 & 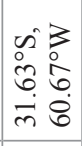 & 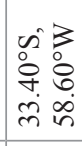 & 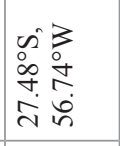 & 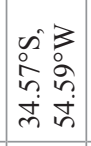 & 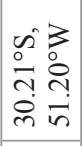 & 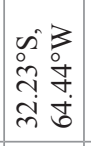 & 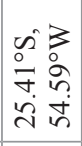 & 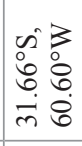 & 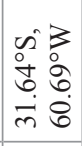 & $\begin{array}{ll}\tilde{w} & 3 \\
0 & 0 \\
i & 0 \\
\infty & \infty \\
\dot{j} & \dot{1} \\
m & i n\end{array}$ & 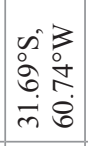 & 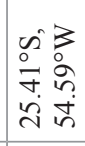 \\
\hline 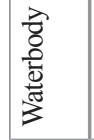 & $\begin{array}{l}: \\
0 \\
2 \\
0 \\
0 \\
0 \\
\simeq\end{array}$ & $\stackrel{\vec{\Delta}}{\stackrel{\vec{\alpha}}{\alpha}}$ & $\stackrel{\vec{\Delta}}{\vec{\alpha}}$ & 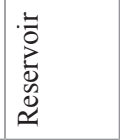 & : & 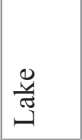 & $\begin{array}{l}: \\
0 \\
0 \\
0 \\
0 \\
0 \\
\simeq 1\end{array}$ & $\begin{array}{l}\vdots \\
0 \\
2 \\
0 \\
0 \\
\simeq\end{array}$ & $\stackrel{\vec{D}}{\Delta}$ & 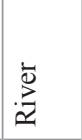 & $\stackrel{\vec{\Delta}}{\vec{\alpha}}$ & $\stackrel{\vec{\Delta}}{\vec{\Delta}}$ & 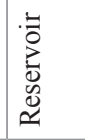 \\
\hline 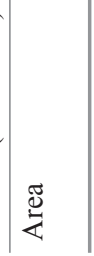 & 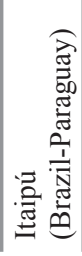 & 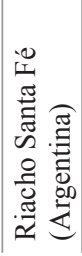 & 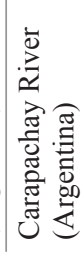 & 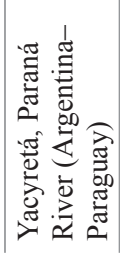 & 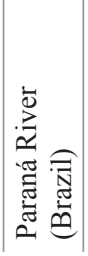 & 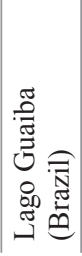 & 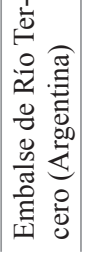 & 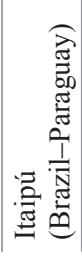 & 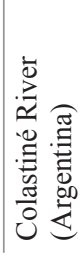 & 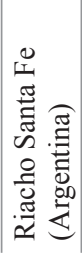 & 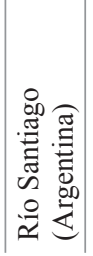 & 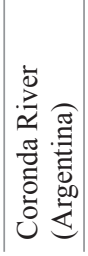 & 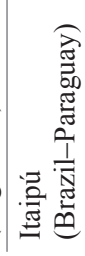 \\
\hline
\end{tabular}




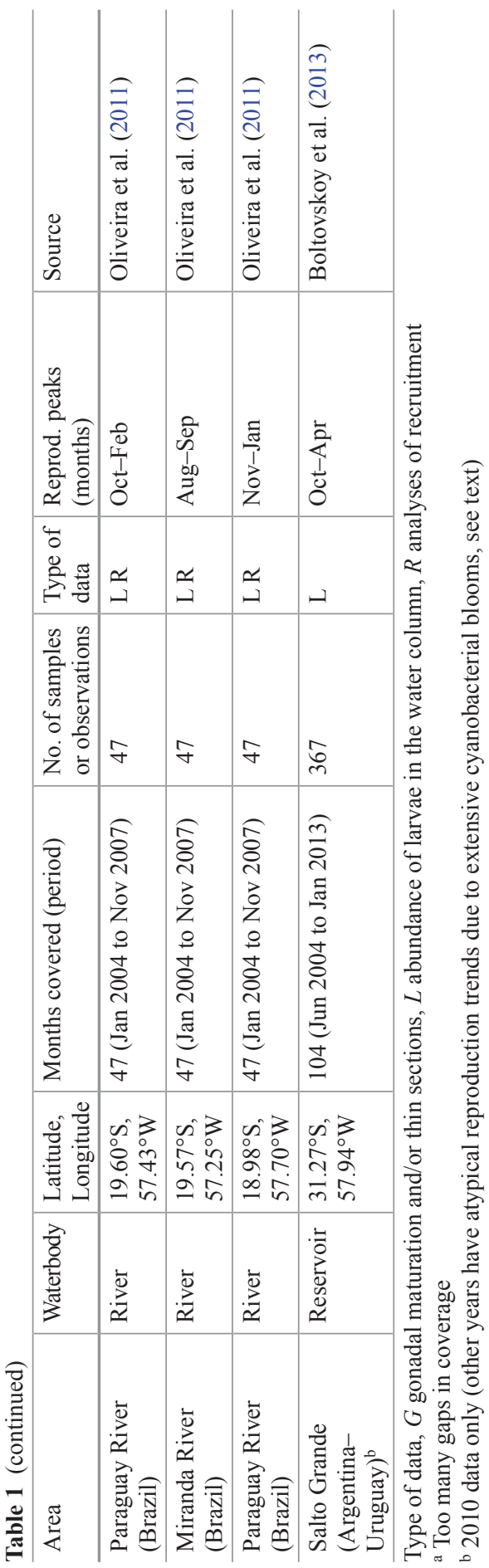


Examination of the literature indicates that larval densities are generally well coupled with recruitment of settled juveniles, but gonadal maturation studies can yield somewhat dissimilar results. This outcome, which may at first seem puzzling, is understandable when one takes into account that the two parameters reflect different aspects of the same reproductive process (see below).

\section{Reproductive Strategy: Evidence from Gonadal Cycles}

The reproductive cycle of L. fortunei in Asia was described by Morton (1982), augmenting an earlier study (Morton 1977) of recruitment and population dynamics of the species in Plover Cove reservoir in Hong Kong at latitude $22^{\circ} \mathrm{N}$. The reservoir was constructed by the damming of a coastal inlet, pumping out the seawater and allowing it to fill from the natural catchment and newly arriving water from China. The species was first recorded from Plover Cove reservoir in 1969, although it had probably arrived in Hong Kong's potable water supply around 1965-1966 (Morton 1977).

Analysis of histological sections of the gonads of $L$. fortunei from Plover Cove reservoir was carried out from October 1971 to February 1974 inclusive (Morton 1982). As with all mytiloids, because the intestine (other than the stomach) does not occur in the visceral mass, this plus the mantle tissues beneath the shell dorsal to their ventral margins (Morton 1973) are occupied wholly by the paired, left and right, maturing gonads (see Chapter "The Biology and Anatomy of Limnoperna fortunei, a Significant Freshwater Bio-Invader: Blueprints for Success", and Figs. 4, 15 therein). L. fortunei is dioecious; in Hong Kong, not one hermaphrodite was identified from the $\sim 300$ individuals encompassing a range of shell sizes in the 29-month histological study by Morton (1982). Later studies based on South American populations, however, identified low $(<0.6 \%)$ proportions of simultaneous hermaphroditism (e.g., Darrigran et al. 1998, in the Río de la Plata estuary; Uliana and Callil 2006, in the Paraguay River).

When ripe, male and female gametes are discharged via left and right gonadal apertures situated at the surface of the visceral mass in the supra-branchial chamber of the outer demibranches of the ctenidia. They are then released via the exhalant siphon for external fertilization.

In Hong Kong, L. fortunei grows fast, reaching a shell length between 15 and $16 \mathrm{~mm}$ in about the first 5 months post recruitment and, by 10 months, individuals are certain to become sexually mature. In South America, sexual maturity was observed to vary seasonally beginning at 5-6 mm in winter-spring, and at 7-10 $\mathrm{mm}$ in autumn (Darrigran et al. 1999). In Hong Kong, during the first year of life, individuals are predominantly (>65\%) females (Morton 1982), but in South America, a slight predominance of males has been observed (45\% males to $40 \%$ females, the remainder being represented by sexually undifferentiated individuals; Darrigran et al. 1999).

The gametogenic cycle of L. fortunei in Hong Kong was interpreted from histological sections (Morton 1982) and categorized into five phases as follows (Fig. 1): 
Males
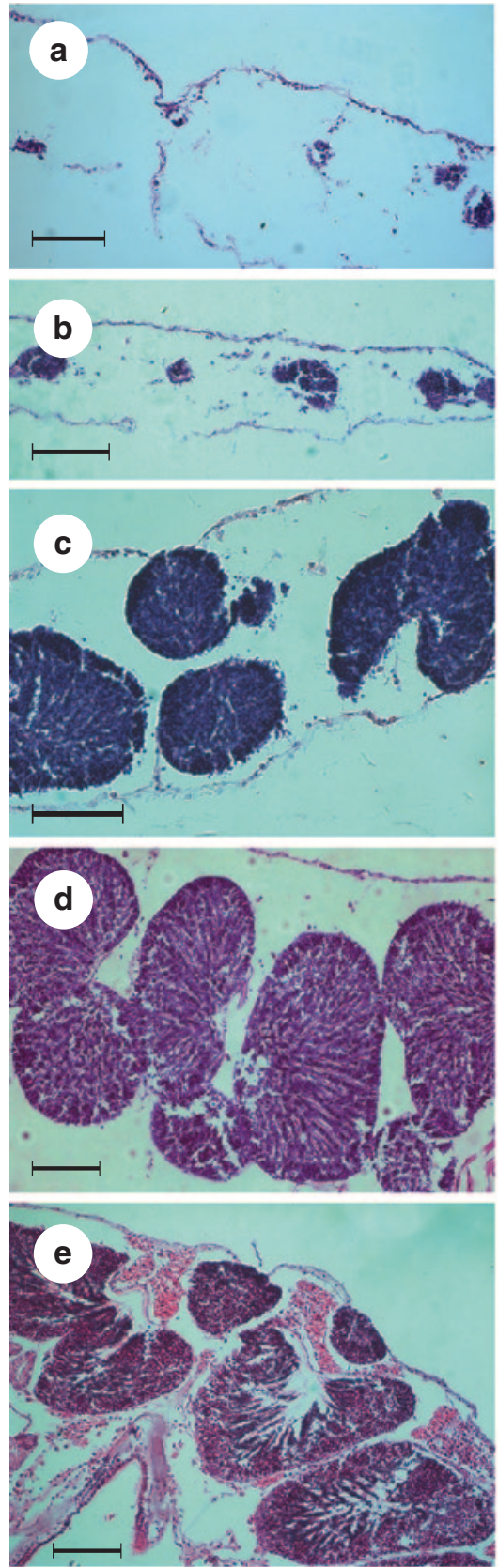

Females
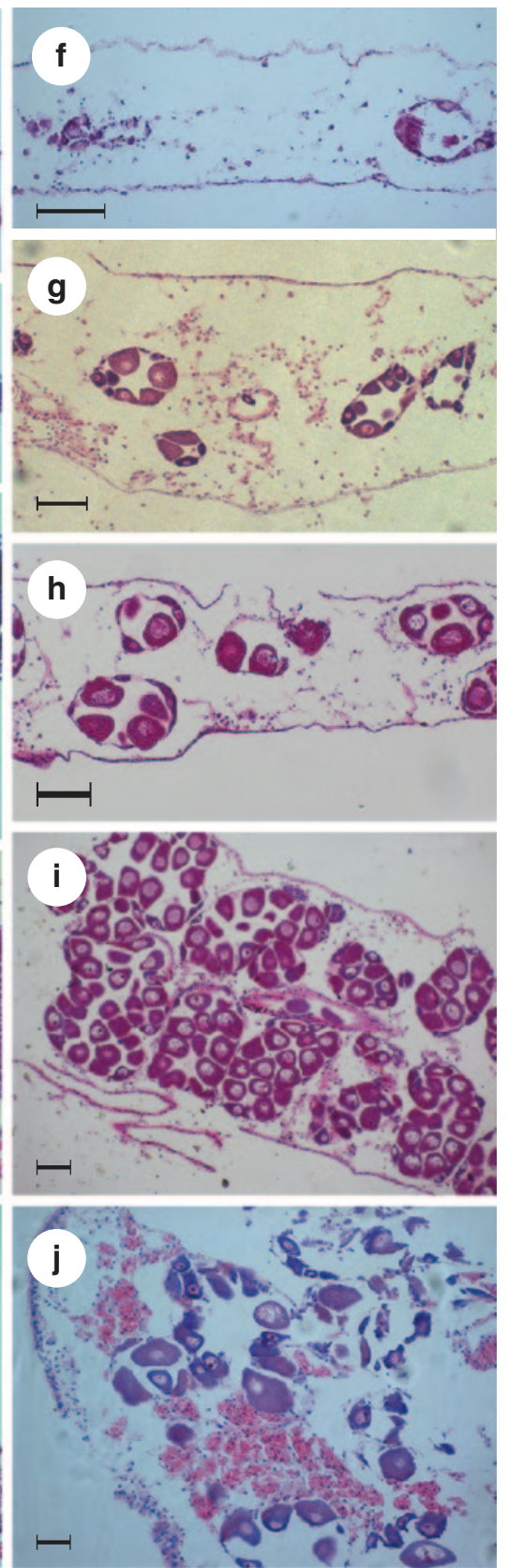

Fig. 1 Photomicrographs of the five stages of gametogenesis in males and females of Limnoperna fortunei. a, f Primordia; b, $\mathbf{g}$ developing; $\mathbf{c}, \mathbf{h}$ maturing; $\mathbf{d}$, i mature; $\mathbf{e}, \mathbf{j}$ partially spent with resorption of remaining undischarged gametes and simultaneously new growing ova attached to the epithelial wall of the ovarian follicle (j). Scale bars: $100 \mu \mathrm{m}$ 
(1) inactive, (2) developing, (3) maturing, (4) mature, and (5) spent. In a similar study based on Brazilian populations, four gametogenic stages for both sexes were defined (Callil et al. 2012). In Hong Kong, during January-February and July-August, both male and female gonads were inactive and comprised small, primordial, seminiferous tubules and ovarian follicles, respectively (Fig. 1). The tubules comprised a thin germinal epithelium producing round, lightly staining, primary spermatocytes $\sim 5 \mu \mathrm{m}$ in diameter. The follicles are comprised of germinal epithelium from which small oocytes, each with a clear, vesicular nucleus and a distinct nucleolus, were developing. In March and September, the seminiferous tubules had enlarged and comprised primary and more darkly staining secondary spermatocytes $2.5 \mu \mathrm{m}$ in diameter with a few spermatids between 1.5 and $2.0 \mu \mathrm{m}$ in diameter occurring in the follicle lumina (Fig. 1). At this time too, ovarian follicles still possessed narrow lumina, although the epithelial walls of these were producing broadly stalked oogonia with a maximum diameter of $10 \mu \mathrm{m}$ (Fig. 1). By April-May and October, gametogenesis was progressing and the seminiferous tubules and ovarian follicles had increased in size substantially (Fig. 1). In the former, there were considerably more spermatids being produced and a few spermatozoa. In the latter, the oogonia had attained an average diameter of $30 \mu \mathrm{m}$ but were still attached to the epithelial wall by a narrower, more pinched stalk. The testes and ovaries were considered to be mature from May to June and November to December. At these times, the seminiferous tubules comprised many primary and secondary spermatocytes and spermatids, but the central lumina of each tubule was full of slipper-shaped spermatozoa arranged in radial chords and forming lamellae with their heads projecting towards the surrounding and the still active germinal epithelium (Fig. 1). Coincidentally, the follicles were packed with, now detached and rounded, ova some $60 \mu \mathrm{m}$ in diameter and each with a darkly staining nucleus $10 \mu \mathrm{m}$ in diameter (Fig. 1). These mature ova possessed only a little yolk and can thus be classified as oligolecithal. By December-January and July, gonads were spent (Fig. 1). They comprised empty tubules and follicles undergoing a generalized pattern of size reduction and resorption of the remaining gametogenic primordia and un-discharged gametes. Knowing, however, that another cycle of gametogenesis will soon begin in each adult surviving into a new life-cycle phase or maturing juvenile, it is clear that the spent phase lasts but for a short period.

The gonadal cycle exhibited by L. fortunei in Hong Kong comprised two phases of reproductive activity each year. During January-February and July-August, the gonads were in a state of regression. These months coincided with the coldest (16$17^{\circ} \mathrm{C}$, winter $)$ and hottest $\left(27-28^{\circ} \mathrm{C}\right.$, summer $)$ water temperatures in the reservoir. As temperatures subsequently warmed and cooled, respectively, gametogenesis proceeded, ultimately resulting in gonadal maturity from May to June and November to December. These two phases were followed by gamete release.

In contrast to this pattern, Choi and Shin (1985) estimated that, in South Korea, at a latitude of $\sim 38^{\circ} \mathrm{N}, L$. fortunei showed a unimodal pattern of reproduction over the course of a year with sperm and ova being released in a single event between July and August for a period of only about 15-20 days. This is in contrast to the situation in subtropical Hong Kong where, as identified by Morton (1977, 1982), two cycles of gametogenic activity were recorded each year, although recruitment, 
albeit with summer and winter peaks, occurred for 10 months of the year. Also, South American subtropical and tropical populations have been observed to recruit for up to $>10$ months of the year (Fig. 2; Boltovskoy et al. 2009b). In tropical Asia, it is possible that $L$. fortunei reproduces year round as well, although this has never been studied.

Working on populations from the Río de la Plata estuary shortly after the species was first discovered in the area, Darrigran et al. (1999) recorded mature sperm year round and five major spawning events between July 1992 and November 1994: in September to October 1992, December 1992 to January 1993, May to July 1993, April to June 1994, and October to November 1994. Subsequent results of Darrigran et al. (2003) and Damborenea and Penchaszadeh (2006) indicated that, in the Río de la Plata estuary, L. fortunei produces sperm and oocytes continuously throughout the year, with spawning peaks in spring (September-November) and at the end of summer (February-March).

In Brazil, diverse situations have been described, from uninterrupted breeding throughout the entire year to punctuated breeding with interruptions and more or less extended resting periods (Table 1).

\section{Reproductive Strategy: Evidence from Temporal Series of Larval Densities}

Studies of temporal changes in the densities of larvae in the water column spanning at least 1 year have been carried out repeatedly, both in Japan and in South America (Table 1). A few studies extended over more than 1 year, and at least two surveys monitored larval abundances over periods of 7 (Mata 2011) and $>9$ years (Boltovskoy et al. 2013; Fig. 2).

In South America, the months of highest larval output vary from site to site and from year to year (Fig. 2), but the most usual pattern involves a spring-early summer peak around November-December, and a second, less pronounced, peak in February-March (Fig. 3), seasonally similar to the situation in Hong Kong. Months barren of larvae are either few or absent. Around $80 \%$ of the temporal series performed (Table 1) show that there are at least ten larvae per cubic meter of water for 11-12 months of the year. The remaining $20 \%$ of the studies identified larvae in $7-10$ months of the year.

In Japan, larval production is also associated with the summer, but the reproductive period is considerably shorter. In the reservoirs and rivers investigated, larvae were absent from the water column for 7-8 months of the year, and peak reproduction was clearly concentrated within 1-2 months (Magara et al. 2001; Nakano et al. 2010a; Hamada 2011; Figs. 2 and 3). In the Uji River (Japan), L. fortunei produced recruits during 4 months of the year (June-September; Iwasaki and Uryu 1998).

The highest recorded larval densities of L. fortunei are around 100,000 ind./ $\mathrm{m}^{3}$ (Darrigran et al. 2007; Nakano et al. 2010a), but such values are exceptional. During months of peak reproduction (November through March in the southern 


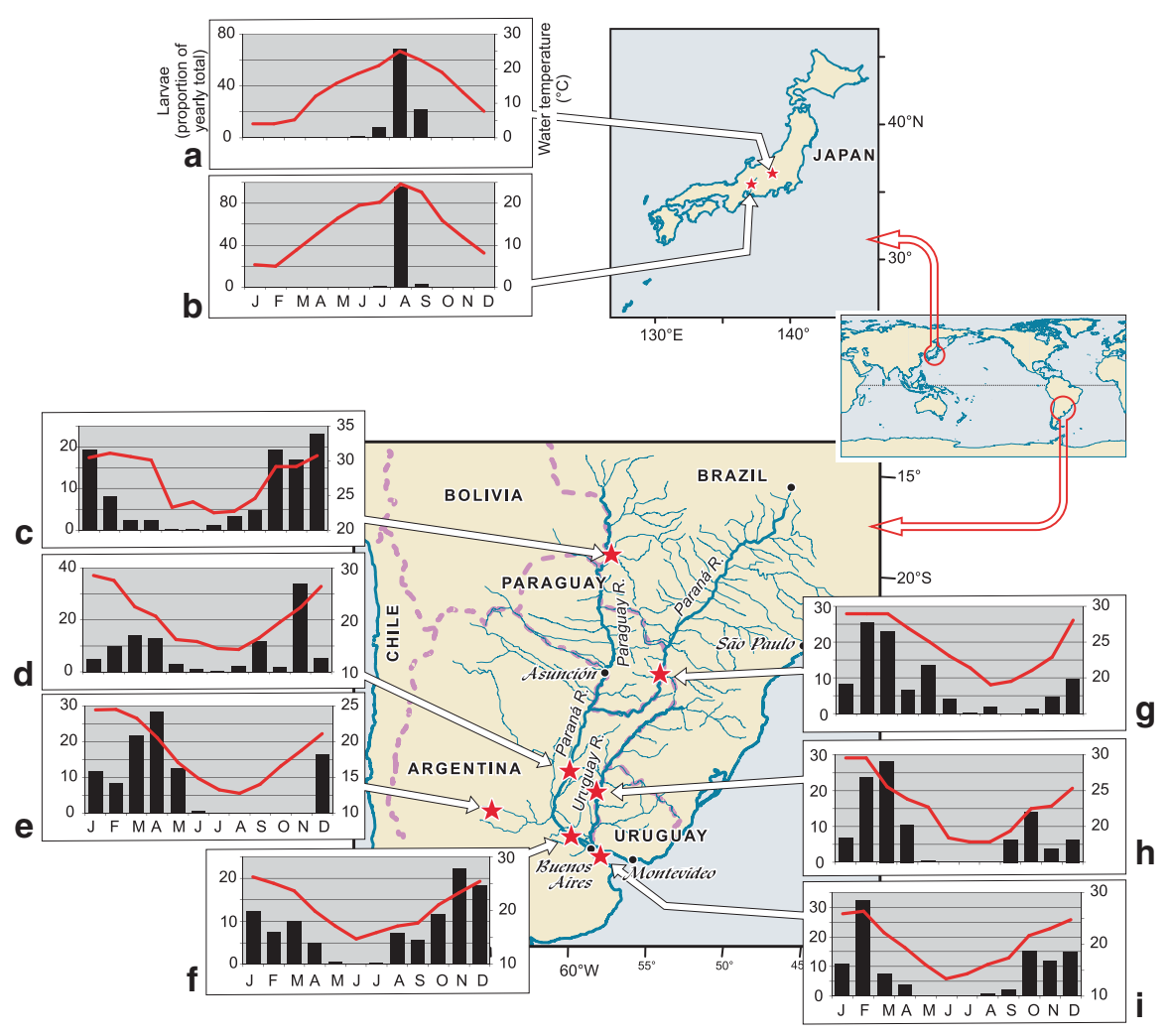

Fig. 2 Reproductive cycles of Limnoperna fortunei in different waterbodies, as shown by the seasonal occurrence of its larvae in the plankton. Bars denote proportions of the yearly total recorded each calendar month (January to December, left $y$-scale; some values are interpolated; overlapping periods for consecutive years are averaged). Red line indicates mean surface water temperature (right $y$-scale). a Yahagi River $\left(35.32^{\circ} \mathrm{N}, 137.14^{\circ} \mathrm{E}\right), 34$ samples collected between May 2007 and February 2010 (based on data from Hamada 2011). b Lake Ohshio $\left(36.22^{\circ} \mathrm{N}, 138.88^{\circ} \mathrm{E}\right), 49 \mathrm{sam}-$ ples collected between August 2007 and November 2008 (based on data from Nakano et al. 2010a, data courtesy of Daisuke Nakano). c Paraguay River $\left(19.60^{\circ} \mathrm{S}, 57.43^{\circ} \mathrm{W}\right), 47$ samples collected between January 2004 and November 2007 (based on data from Oliveira et al. 2011). d Riacho Santa Fe (tributary of the Middle Paraná River) $\left(31.64^{\circ} \mathrm{S}, 60.68^{\circ} \mathrm{W}\right), 33$ samples collected between September 2004 and September 2005 (based on data from Rojas Molina 2010). e Embalse de Río Tercero (32.23 $\left.{ }^{\circ} \mathrm{S}, 64.44^{\circ} \mathrm{W}\right), 40$ samples collected between March 2005 and March 2006 (based on data from Boltovskoy et al. 2009b). f Lower Paraná delta (33.96 $\left.{ }^{\circ} \mathrm{S}, 59.21^{\circ} \mathrm{W}\right), 68$ samples collected between September 1997 and January 1999 (based on data from Boltovskoy and Cataldo 1999). g Itaipú reservoir (Upper Paraná River) $\left(25.41^{\circ} \mathrm{S}, 54.59^{\circ} \mathrm{W}\right), 12$ samples collected between January 2005 and December 2005 (based on data from Mata 2011). h Salto Grande reservoir (Uruguay River) $\left(31.27^{\circ} \mathrm{S}, 57.94^{\circ} \mathrm{W}\right), 37$ samples collected between January 2010 and December 2010 (based on data from Boltovskoy et al. 2013). i Río de la Plata estuary $\left(34.56^{\circ} \mathrm{S}, 58.41^{\circ} \mathrm{W}\right.$ ), 63 samples collected between October 1997 and December 1998 (based on data from Cataldo and Boltovskoy 2000) 
Fig. 3 Seasonal occurrence of Limnoperna fortunei larvae in the water column in South America (mean values based on 25 surveys) and in Japan (mean values based on three surveys)

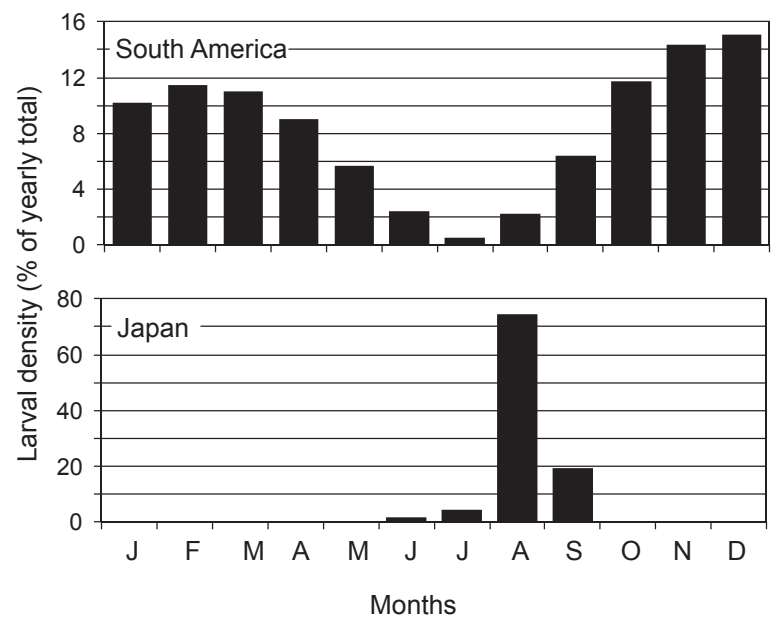

hemisphere), larval densities normally range between 6000 and 7000 ind. $/ \mathrm{m}^{3}$, whereas in June-September, they decline to $<1000$ ind./ $\mathrm{m}^{3}$. Data are more scarce for Japan, but summer peak larval densities are probably higher than those recorded in South America (e.g., around 20,000-35,000 ind. $/ \mathrm{m}^{3}$; Magara et al. 2001; Nakano et al. 2010a), but with no larvae for most of the remaining months in the year.

The larval densities described above are considerably lower than the maxima recorded for Dreissena polymorpha, which can exceed 500,000 ind. $/ \mathrm{m}^{3}$ (Garton and Haag 1993; Smit et al. 1993), suggesting that the zebra mussel has a higher instantaneous fecundity. This does not, however, necessarily imply a higher overall fecundity, because the reproductive period of D. polymorpha is often considerably shorter (Karatayev et al. 2007; Boltovskoy et al. 2009b; see Chapter "Parallels and Contrasts Between Limnoperna fortunei and Species of Dreissena" in this volume). Adult population densities, on the other hand, seem either similar or slightly higher for L. fortunei (Karatayev et al. 2010).

\section{Differences Between Results: Gonadal Maturation Versus Larval Cycles}

Different methods (larval abundance trends vs. gonadal maturation) have produced different results concerning the timing of the periods of highest reproductive output: Larval cycles point to an almost continuous spring-to-autumn reproduction with two more or less conspicuous peaks around December and February-March (in South America), or a single peak in the middle of summer (Japan, Korea; Fig. 3). Gonadal studies, in turn, identify two or more discrete pulses, sometimes even in the middle of winter (Morton 1982; Darrigran et al. 1999, 2003). These differences are most probably due to the fact that the two types of observations reveal different aspects of the same process. That is, larval cycles integrate the reproductive output 
of extensive mussel beds dispersed over large areas, whereas gonadal data pinpoint with high precision the ripening and spawning of more or less isolated individuals or spatially restricted clusters.

Larvae of $L$. fortunei collected at any one location are produced by adults dispersed over large areas upstream from the collection site. The time required for a fertilized egg to reach the pediveliger stage, when it is ready to settle, is ca. 20 days at $20^{\circ} \mathrm{C}$ (Cataldo et al. 2005; see Chapter "Larval Development of Limnoperna fortunei" in this volume) and probably longer at lower temperatures (L. fortunei reproduces at water temperatures as low as $15-17^{\circ} \mathrm{C}$; Morton 1977; Cataldo and Boltovskoy 2000; Brugnoli et al. 2011). At current velocities of $\sim 3-5 \mathrm{~km} / \mathrm{h}$, not uncommon in many rivers, larvae caught at any one site could thus have originated from as far as $2000 \mathrm{~km}$ upstream. A plankton sample therefore typically integrates the reproductive output of hundreds to millions of $L$. fortunei beds located upstream from the sampling site.

Gonadal maturation, on the other hand, is based on the analysis of a few individuals collected over a small area, usually the same throughout the entire cycle analyzed. As suggested for other bivalves (Garton and Haag 1993), while restricted beds of $L$. fortunei may spawn synchronously, when larger areas are considered, the lack of reproductive synchronicity between populations results in a continuous breeding season and discrete spatfalls are not recognizable in the plankton (Boltovskoy et al. 2009b). As a consequence, both punctuated and continuous reproduction modes have been reported by the same authors when using histological data and larval counts in plankton samples, respectively (Darrigran et al. 1999, 2002).

While inducing $L$. fortunei to spawn using artificial stimuli in laboratory conditions is fairly easy (Cataldo et al. 2005), detecting the timing, frequency, and intensity of spawning events of restricted beds in the field poses serious difficulties and has not been achieved hitherto. With the aid of an experimental device that mimicked natural conditions, Cataldo and Boltovskoy (unpublished) sampled the prefiltered water, bathing a cluster of ca. 2000 adult individuals in order to detect spawning. Although the experiment was carried out at a time of peak reproduction, after a week of uninterrupted filtration, no ova were observed. Admittedly, the observational period was limited, but the result seems to support the notion that reproduction of discrete clusters is not continuous, as suggested by the presence of larvae in the plankton, but punctuated, as deduced from gonadal maturation studies. Given the clear advantages of epidemic over asynchronous spawning (particularly for a species whose distribution encompasses many thousands of kilometers and, due to its requirement for hard substrata, is extremely patchy), it is hard to envision how $L$. fortunei manages to produce such impressive numbers of offspring if it lacks mechanisms for synchronizing the liberation of its gametes. Although epidemic spawning is characteristic of marine invertebrates, and is less common in freshwater organisms (Olive 2002), L. fortunei is a member of a typically marine bivalve superfamily (Mytiloidea) and, as such, shares many traits with most of its marine relatives, notably a rather extended free-swimming larval stage.

It is concluded that although both of these methods to identify spawning (gonadal thin sections and larval counts) yield useful data, the information conveyed by them 
is dissimilar. Studies based on the assessment of gonadal maturation focus on the reproductive behavior of individuals and, by extension, of the species. They convey precise information on the number and timing of reproductive events in any one breeding season and are, probably, the most promising paths for studies of fecundity. Larval counts, on the other hand, are more meaningful in terms of the overall ecology of $L$. fortunei and of the biota that interacts with it. For fouling control studies, the information conveyed by larval counts is more useful as it better allows the pinpointing of periods when industrial installations are particularly vulnerable to fouling by this species.

\section{Triggers of Reproduction}

"What triggers spawning?" is a key question associated with surveys of the reproductive behavior of $L$. fortunei. The variable that has been recurrently observed to covary with reproduction is water temperature (Boltovskoy et al. 2009b; Fig. 2). Several authors have suggested that $15-18^{\circ} \mathrm{C}$ is the threshold value below which production of larvae is near zero (Morton 1977; Choi and Shin 1985; Cataldo and Boltovskoy 2000; Nakano et al. 2010a; Brugnoli et al. 2011), but this threshold is obviously not applicable to tropical waterbodies where water temperatures never fall below these values. Even in these locations, however, there usually is a well-defined period of reproductive relaxation, which invariably occurs during the coolest months (Canzi et al. 2005; Boltovskoy et al. 2009b; Mata 2011; Oliveira et al. 2011; Fig. 2c and g). For Salto Grande reservoir (Argentina-Uruguay), where surface water temperatures vary from 14 to $32^{\circ} \mathrm{C}$, densities of $L$. fortunei larvae have been estimated weekly between June 2004 and 2014. Lowest larval densities occurred between $\sim 1$ June and 15 August, at temperatures around $14-24^{\circ} \mathrm{C}$ (mean: $18^{\circ} \mathrm{C}$ ). However, of the 87 plankton samples collected between 1 June and $15 \mathrm{Au}-$ gust (2004 through 2013), only ten contained no larvae at all (i.e., $<0.5$ larvae/ $\mathrm{m}^{3}$ ). Boltovskoy et al. (2009b) suggested that, regardless of ambient temperature, L. fortunei needs a resting period in order to resume gametogenesis, as has been reported for other invertebrate species (McMahon and Bogan 2001). Interestingly, this behavior differs from that of D. polymorpha in artificially heated reservoirs and laboratory conditions at temperatures permanently $>12{ }^{\circ} \mathrm{C}$, where the species has been reported to produce larvae year round (Stanczykowska 1977; Lewandowski 1982b; Nichols 1993). Nevertheless, in the temperate and warm waterbodies of southern North America, spawning does not begin until water temperatures rise to $>20^{\circ} \mathrm{C}$ (Nichols 1996). In southern England, larval settlement of D. polymorpha begins at a temperature of $\sim 15^{\circ} \mathrm{C}$ (Morton 1969).

While there is little doubt that temperature plays a key role in the reproductive cyclicity of $L$. fortunei, there most probably are other factors that also influence both the timing and the intensity of spawning events. Their association with reproduction, however, is less clear and mostly based on circumstantial evidence (unless they range outside of the normal levels of tolerance of the species, in which 
case they affect all vital traits, including reproduction; Nakano et al. 2010a). In his studies of Plover Cove reservoir, Morton (1982) remarked that $\mathrm{pH}$, salinity, and dissolved oxygen may be associated with gametogenesis and spawning. His results suggested that spawning takes place at times of high temperatures and low dissolved oxygen levels in summer and at low temperatures with high dissolved oxygen levels in winter. Oliveira et al. (2011) argued that, in addition to temperature, dissolved oxygen, and calcium levels, $\mathrm{pH}$, water velocity, suspended solids, and chlorophyll $a$ concentrations may be instrumental in modulating larval numbers in the upper Paraguay River. Changing conditions associated with flood-drought cycles characteristic of many large South American rivers have also been suggested as important factors involved in the reproduction of L. fortunei, particularly in areas where temperatures are high year around (Callil et al. 2012).

The availability of food, which was found to be important in determining the frequency of reproduction in D. polymorpha (Gist et al. 1997), may also play a role in the extension of the reproductive period of $L$. fortunei. Boltovskoy et al. (2009b) noted that, in practically all the South American waterbodies surveyed, the winter phase of reproductive relaxation spanned 1.8-3 months, with the exception of the reservoir Embalse de Río Tercero, where larvae were virtually absent from the waterbody for almost half the year (Fig. 2e). Water temperatures in this reservoir were not significantly different from those of other sites, suggesting that this factor is unlikely to account for such a reproductive difference. On the other hand, suspended particulate organic matter in Embalse de Río Tercero (around 0.5-1 mg/L) was much less abundant than in the other waterbodies (around $8 \mathrm{mg} / \mathrm{L}$ ), which may point to food supply as a significant factor that affects reproductive output.

\section{Vertical Distribution of Larvae}

A few studies have investigated the vertical distribution of L. fortunei larvae in the water column. In rivers, turbulent flow normally precludes the development of vertical stratification and physical, chemical, and biological properties, including L. fortunei larvae and other plankton, are evenly distributed from top to bottom (Fig. 4). In lentic environments, on the other hand, contrasting situations have been described. In Palmar reservoir (Uruguay), Brugnoli et al. (2011) did not identify significant differences in the concentrations of $L$. fortunei veligers at different depths. In contrast, in Lake Ohshio (Japan), veligers were more abundant near the bottom (ca. $18 \mathrm{~m}$ ) and at mid-depths than in the uppermost 2-m layer (Nakano et al. 2010a). Differential colonization rates at different depths of the same waterbody could also point to differences in preferred larval depth (Morton 1977), but interpretation of these patterns is complicated by possible dissimilarities in the survival of recruits, including the effects of predation (Nakano et al. 2010b). In any case, it would be reasonable to expect that at least older larvae, that is, those nearing the settling stage, are more abundant closer to their final destination - the epibenthos - than elsewhere in the water column (as observed in laboratory conditions, see Chapter "Larval Development of Limnoperna fortunei" in this volume). 
Fig. 4 Densities of Limnoperna fortunei larvae, copepods, and cladocerans at different depths in the Paraná de la Palmas River (Lower Paraná River delta; $34.29^{\circ} \mathrm{S}$, $58.56^{\circ} \mathrm{W}$ ) recorded on 3 March 2003 (unpublished authors' data)

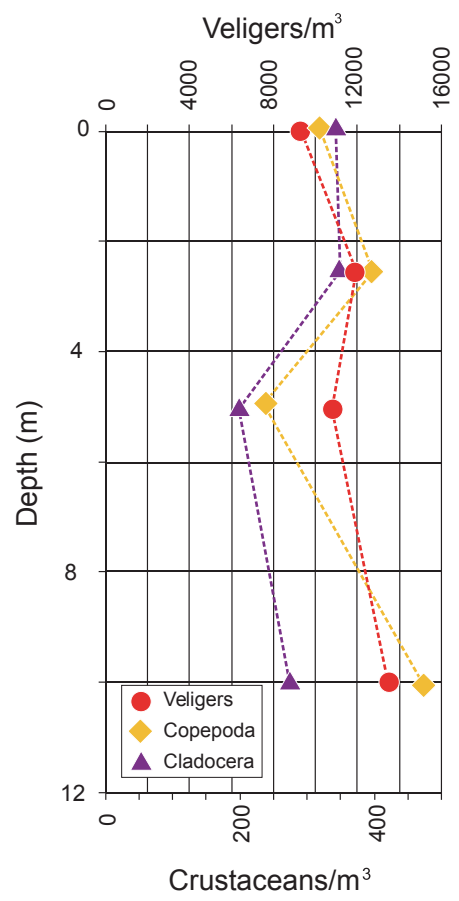

\section{Factors Affecting Larval Densities}

In addition to seasonality, several other factors can modulate larval densities in the water column. Some of these have been investigated, including distance from suitable substrata, time after colonization, the effects of cyanobacterial blooms, and sample-to-sample variability.

\section{Distance from Suitable Substrata}

Although adult L. fortunei can use a variety of substrata for attachment (see Chapter "Limnoperna fortunei Colonies: Structure, Distribution and Dynamics" in this volume), hard, immobile surfaces, like stone and wood, are normally favored. Such substrata, especially immobile boulders, are often scarce in natural lotic and lentic systems. In South America, in particular, the main waterbodies colonized by L. fortunei are large, lowland, riverine systems, whose streambeds are characterized by fine, unconsolidated sediments, unfit for colonization by L. fortunei. Over large river stretches, therefore, the only hard substrata available are man-made structures associated with populated areas, such as piers, groynes, pilings, breakwaters, and revetments. Larval densities may thus be higher in the vicinity of these structures than farther away. Figure 5 shows the results of a transect in the Río de la Plata estuary, off Buenos Aires, 
Fig. 5 Larval densities recorded along a transect perpendicular to a coast modified by a concrete coastal revetment densely populated by adult mussels off Buenos Aires, on 11 December 2002. (unpublished authors' data)
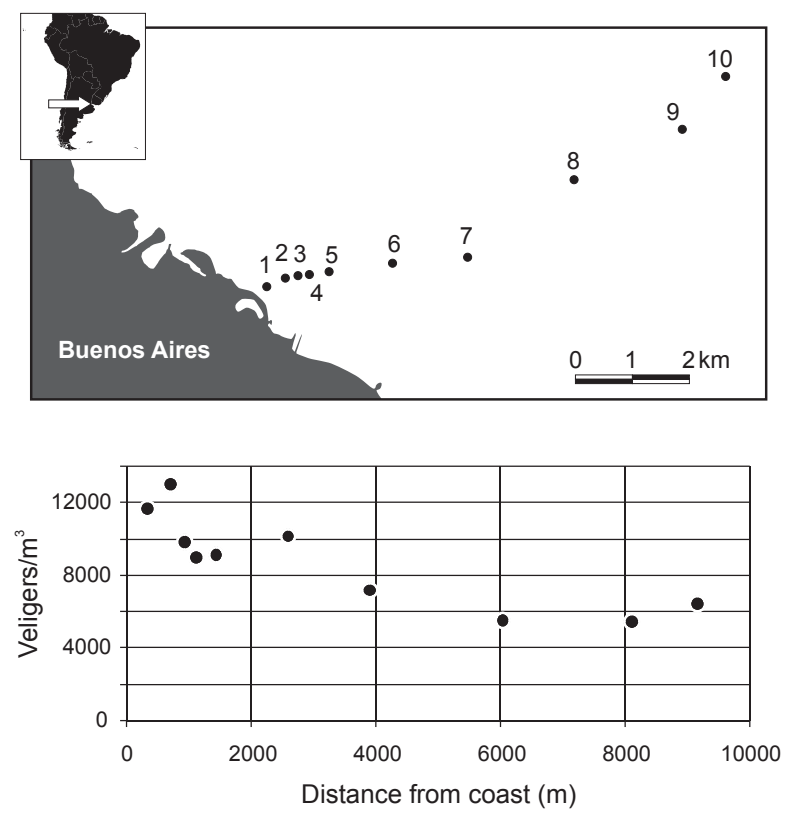

roughly perpendicular to a coastal sector modified entirely by a concrete revetment. Larval numbers fell from around 12,000 ind. $/ \mathrm{m}^{3}$ next to the man-made concrete wall (densely populated by adult individuals) to $6000 \mathrm{ind} . / \mathrm{m}^{3}$ at $6-10 \mathrm{~km}$ from this substratum (the bottom in this area is silt-mud). While this difference is well within the range of the sample-to-sample variability (Fig. 6), the decreasing trend is consistent, suggesting that distance from the coast plays a significant role in influencing population numbers. This effect is probably of little importance when analyzing seasonal trends in larval abundance at a fixed site, but site-to-site comparisons may be affected significantly.

\section{Time After Colonization}

Larval concentrations also depend strongly on the time elapsed after initial colonization of the waterbody. Data from Itaipú reservoir, which was colonized by $L$. fortunei around 2000 (Zanella and Marenda 2002), indicate that mean annual larval densities were only 106 ind. $/ \mathrm{m}^{3}$ in 2002,512 ind. $/ \mathrm{m}^{3}$ in 2003 , and $2000-2500$ ind./ $\mathrm{m}^{3}$ in 2004-2005, suggesting that the spread of beds upstream from the sampling site was responsible for this increase (Canzi et al. 2005). In 2006, larval densities fell to ca. 1400 ind. $/ \mathrm{m}^{3}$ and varied thereafter at around $1000-1500 \mathrm{ind} . / \mathrm{m}^{3}$ until 2008 (Mata 2011; Fig. 7). This decline and subsequent plateau could point to stabilization of the adult population densities in the reservoir, although the time elapsed since 
Fig. 6 Densities of Limnoperna fortunei larvae, copepods, and cladocerans recorded throughout a $24-\mathrm{h}$ period in Honda River (Lower Paraná River delta; $34.32^{\circ} \mathrm{S}, 58.53^{\circ} \mathrm{W}$ ) on $4-5$ March 2003 (unpublished authors' data)

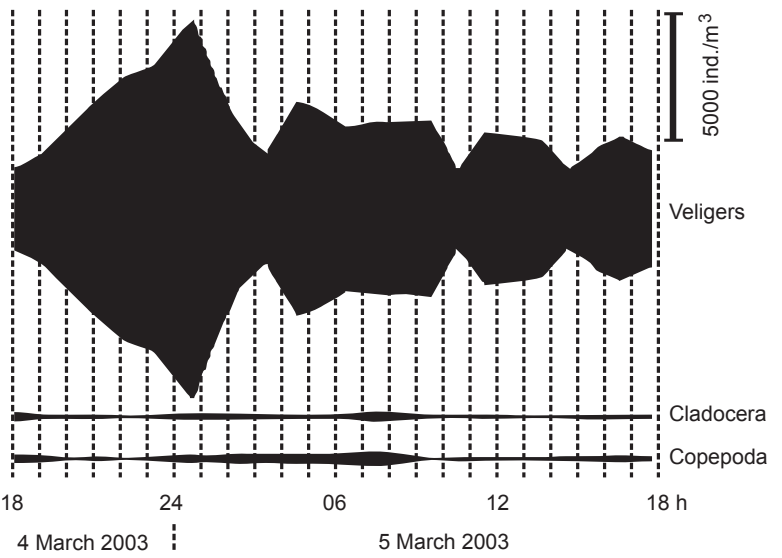

Date and time

Fig. 7 Mean densities of Limnoperna fortunei larvae in Itaipú reservoir between 2002 and 2008 (based on data from Canzi et al. 2005; Pestana et al. 2008; Boltovskoy et al. 2009b; Mata 2011)

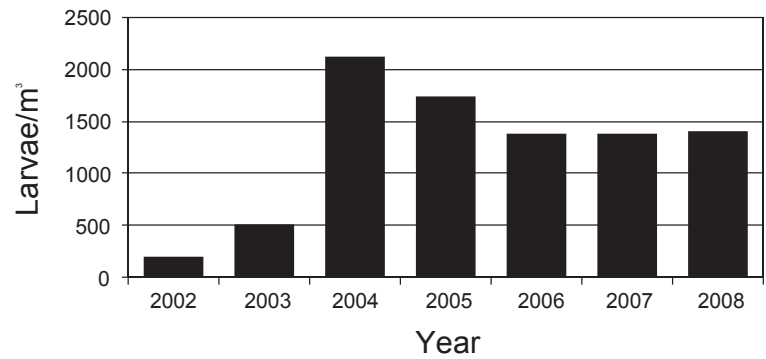

initial colonization appears short for this process. Populations of invasive bivalves, including $D$. polymorpha, have been suggested to follow a so-called boom-bust cycle (Stanczykowska 1977), stabilizing at around 7-12 years post introduction (Burlakova et al. 2006; Boltovskoy et al. 2009a, 2009b). Nevertheless, several other population modes have also been described, some of them involving large cyclical or irregular fluctuations (Strayer and Malcom 2006).

Although the scarce evidence available suggests that larval densities increase in response to adult population growth, no direct proof of a significant correlation between the numbers of adults and those of their planktonic larvae has yet been provided. This relationship may not be as trivial as it seems. Several surveys of $D$. polymorpha have failed to establish a clear relationship between adult population size and larval density (Stanczykowska 1977; Garton and Haag 1993; Nalepa et al. 1995), with some authors suggesting that larval numbers in the plankton may be governed by other factors, such as the age structure of the adult population (Lewandowski 1982a) and water levels (Smirnova et al. 1993). 


\section{The Effects of Cyanobacterial Blooms}

Another factor that has been shown to impact reproductive periods and larval numbers significantly is the development of cyanobacterial blooms. On the basis of 9 years of observational data in Salto Grande reservoir (on the Uruguay River, Argentina-Uruguay), Boltovskoy et al. (2013) showed that reproduction by L. fortunei was interrupted during dry summers (January-April), coinciding with periods of peak Microcystis spp. growth and low water discharge levels - which favor the buildup of algal biomass. Conversely, wet summers with high discharge rates were characterized by low densities of Microcystis spp. and high numbers of L. fortunei larvae in the water column (Fig. 8). Laboratory experiments showed that microcystin-LR (produced by toxic strains of several Cyanobacteria) is highly toxic to $L$. fortunei larvae, eliminating $58-100 \%$ of individuals in $48 \mathrm{~h}$ at $10-20 \mu \mathrm{g} / \mathrm{L}$ (Boltovskoy et al. 2013). Cyanobacterial blooms in this reservoir are particularly strong in late summer-autumn, often suppressing the December/January to April reproductive pulse completely (Fig. 9). While associations between microcystin and larval mortality are beyond doubt, the toxin may also affect other aspects of $L$. fortunei reproduction, such as gamete production and survival, fertilization, and hatching. Suppression of reproduction due to high microcystin concentrations is most likely in subtropical and tropical lakes and reservoirs (Soares et al. 2013), especially when
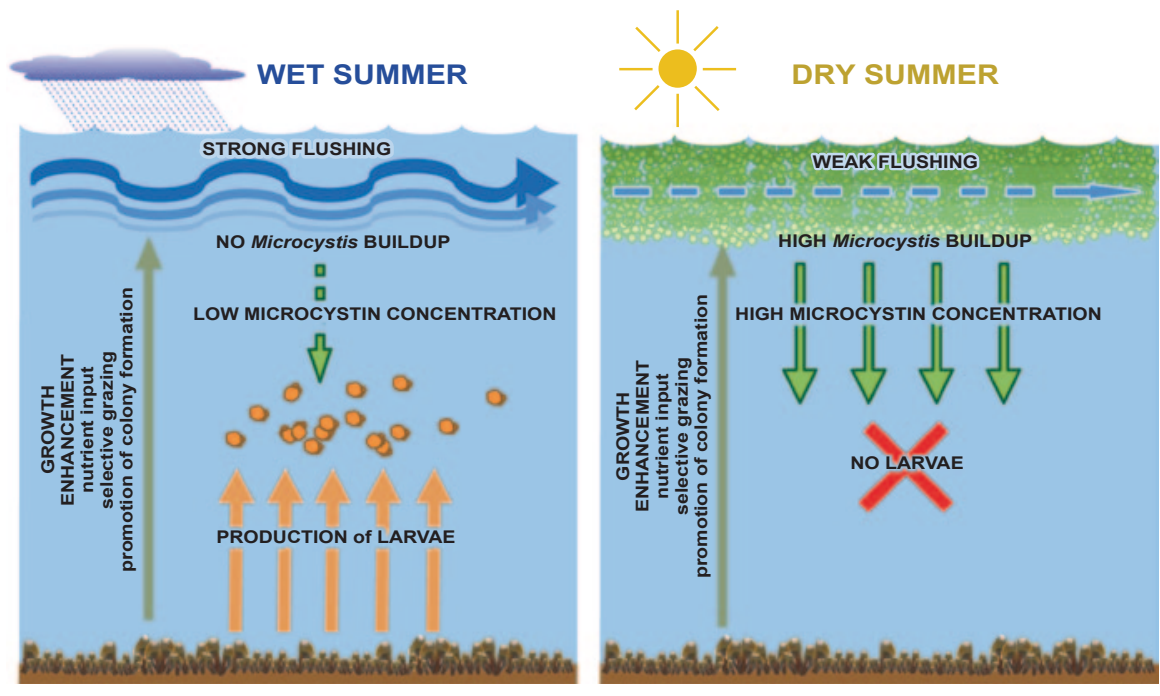

Fig. 8 Schematic diagram of cause-effect relationships between Microcystis spp. blooms and Limnoperna fortunei reproduction in Salto Grande reservoir (Argentina-Uruguay). During rainy summers, high discharge rates preclude Microcystis spp. buildup and microcystin levels are low in the water, allowing for normal production of larvae. During dry summers, weak flushing and strong thermal vertical stratification favor Microcystis spp. growth and high microcystin concentrations in the water column, which kill L. fortunei larvae precluding reproduction. (Modified after Boltovskoy et al. 2013, with permission from John Wiley \& Sons) 


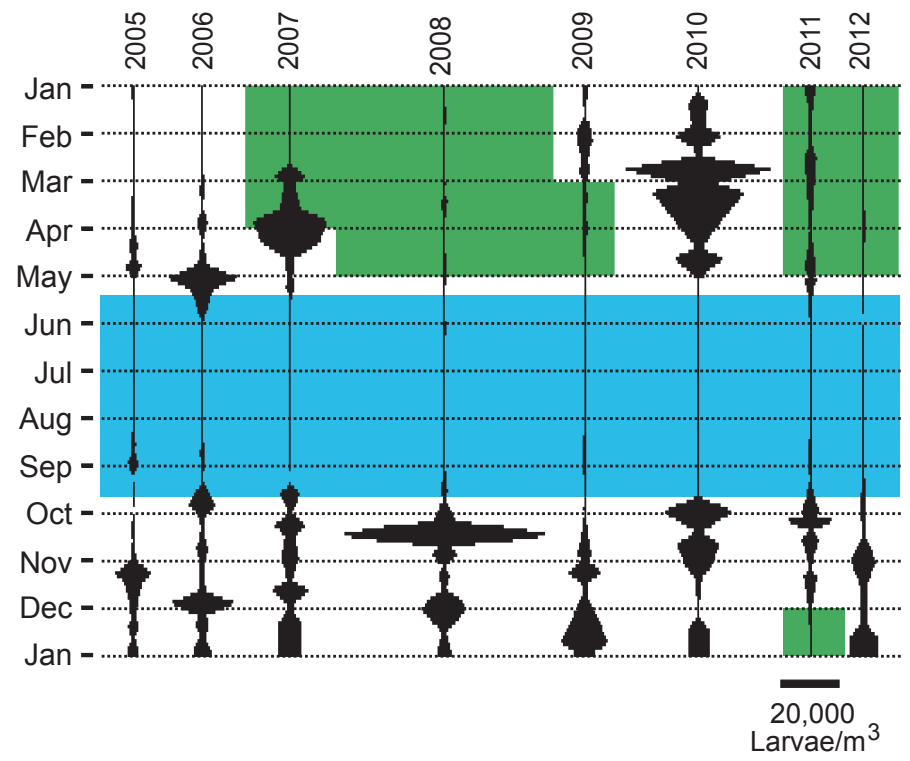

Fig. 9 Densities of L. fortunei larvae in Salto Grande reservoir between 2005 and 2012. Green shading denotes periods of extensive Microcystis spp. blooms (no data for Microcystis are available in 2005 and 2006); light blue shading denotes water temperatures below $21^{\circ} \mathrm{C}$ (mean for 2005-2012; based on data from Boltovskoy et al. 2013)

their drainage areas include agricultural land yielding high nutrient loads. Rivers, on the other hand, rarely host strong blooms, and would thus be less likely to show atypical larval abundance cycles.

In addition to the above, several other factors have been reported to affect the reproductive output of $L$. fortunei. Trematode parasites can inhibit gamete production (Tanaka et al. 2004; see Chapter "Parasites of Limnoperna fortunei" in this volume). Stress-inducing factors, like pollution and low dissolved oxygen levels, can impact many of the species' vital activities and processes, including reproduction (e.g., Morton 1977; Nakano et al. 2010a; Bonel 2011; Oliveira et al. 2011; Bonel et al. 2013).

\section{Sample-to-Sample Variability}

Agreement between surveys indicates that the overall trends in the larval abundance profiles of $L$. fortunei do reflect actual density variations throughout the year but, as with most planktonic abundance estimates, variability is high. The profiles shown in Fig. 6 illustrate abundance estimates for veligers, copepods, and cladocerans obtained at hourly intervals on 4 and 5 March 2003 in the Lower Paraná River delta. Numbers of $L$. fortunei larvae varied between ca. 2000 and almost 16,000 ind. $/ \mathrm{m}^{3}$, or slightly less than one order of magnitude. This variability does not seem to reflect 
the result of reproductive pulses from different $L$. fortunei beds distributed upstream from the sampling site, because copepods and cladocerans showed a similar range of variation. All these samples were collected using a submersible centrifugal pump (rather than towed flow-metered net), thus ensuring precise estimates of the volume of water filtered and precluding any possibility of net clogging. Furthermore, all counts were conducted twice in order to minimize methodological bias. These results underscore the need for intensive, densely packed (in space and/or in time) sampling programs when investigating reproductive output trends.

\section{Concluding Remarks}

Comparison of annual recruitment cycles from several climatic zones leaves little doubt that temperature has an overwhelming importance on the reproductive process. Remarkably, summer maxima differ moderately between the areas where the reproductive cycles of $L$. fortunei have been investigated, but winter minima are quite dissimilar. Lowest values are those where winter minima are around $0-4{ }^{\circ} \mathrm{C}$ (Choi and Shin 1985; Nakano et al. 2010a; Table 2). Here, $>90 \%$ of the reproductive output is concentrated within 1-2 summer months (July and August); there are no larvae in the water column for the rest of the year. In records from the Uji River (Japan), at somewhat higher water temperatures (ca. $13-26^{\circ} \mathrm{C}$ ), L. fortunei produced recruits during 4 months of the year (June-September) (Iwasaki and Uryu 1998). In the southernmost South American localities investigated (Lower Paraná River delta, Río de la Plata estuary), where lowest water temperatures are $\sim 10^{\circ} \mathrm{C}$, larvae are produced for around 5-7 months of the year, but there often are two more or less well-defined peaks - a major one shortly after the winter trough, in November or December, and a second, usually smaller one, around March. Further north in the Río de la Plata watershed (Upper Paraná River, Paraguay River), winter temperature minima are higher $\left(13-14^{\circ} \mathrm{C}\right)$ and the corresponding reproductive relaxation period is shorter. Finally, in subtropical Asia (Hong Kong), where water temperatures vary seasonally between 15 and $32^{\circ} \mathrm{C}$, gonadal activity is present throughout most of the year and, in addition to the summer peak, there also is a peak in February (northern hemisphere winter; Morton 1977). These differences in reproductive activity are summarized in Fig. 10 and show that reproduction is confined to a single summer peak in the northern temperate zone (Korea, Japan). Most interestingly, however, the data show that in the northern (Hong Kong) and southern (South American) subtropics, there are roughly two reproductive peaks, but both occurring in their respective (and opposite) early spring and late summer seasons.

Contrasts between Korea and Japan, on the one hand, and South America, on the other, are very sharp (Fig. 2), but trends anticipated from the corresponding thermal regimes are not always as clear-cut. For example, water temperatures of the Yahagi River (Japan, $10-26^{\circ} \mathrm{C}$ ) are similar to those of the Middle Paraná River (Argentina, $10-29^{\circ} \mathrm{C}$ ), yet larval production is restricted to 1 month in the former, while 


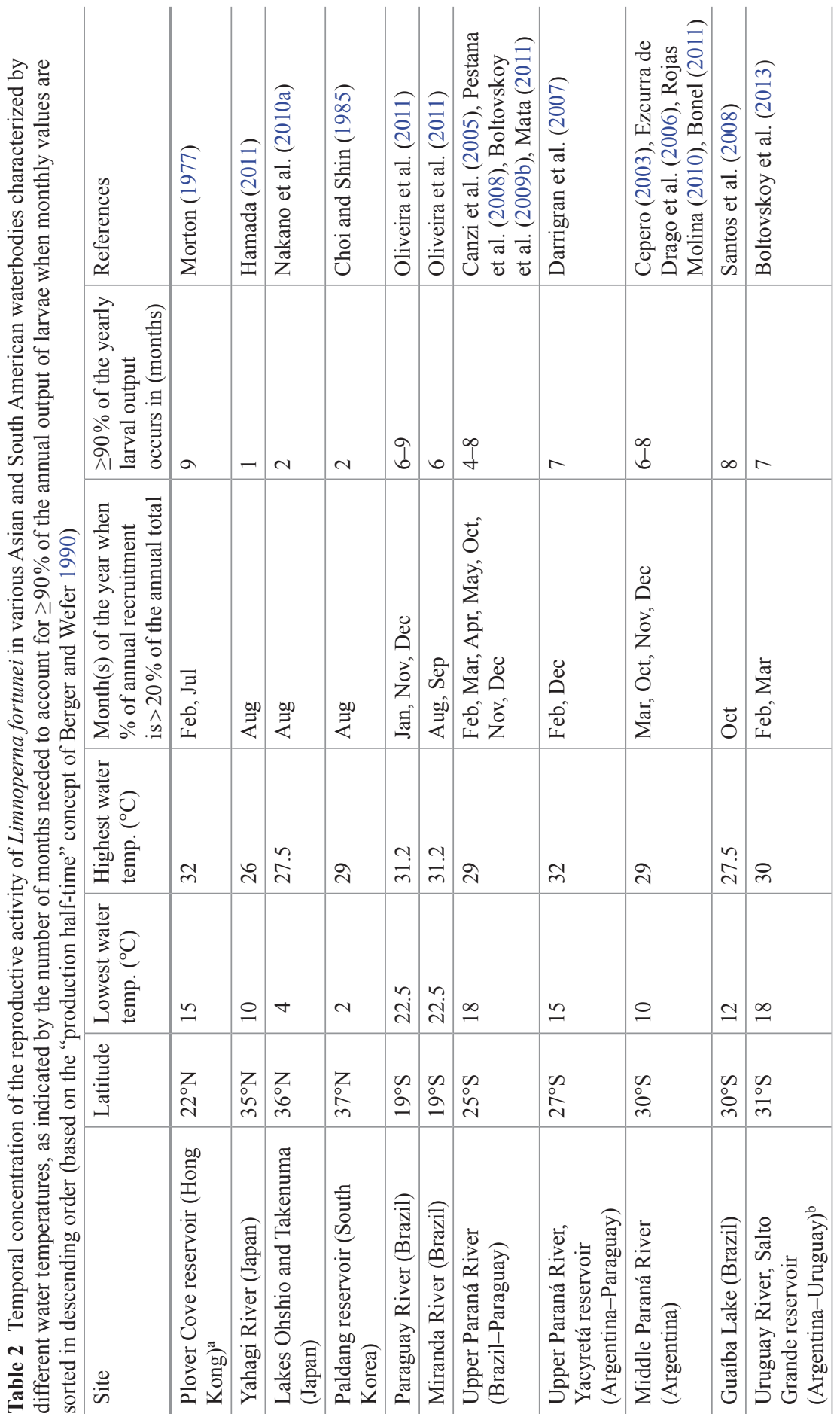




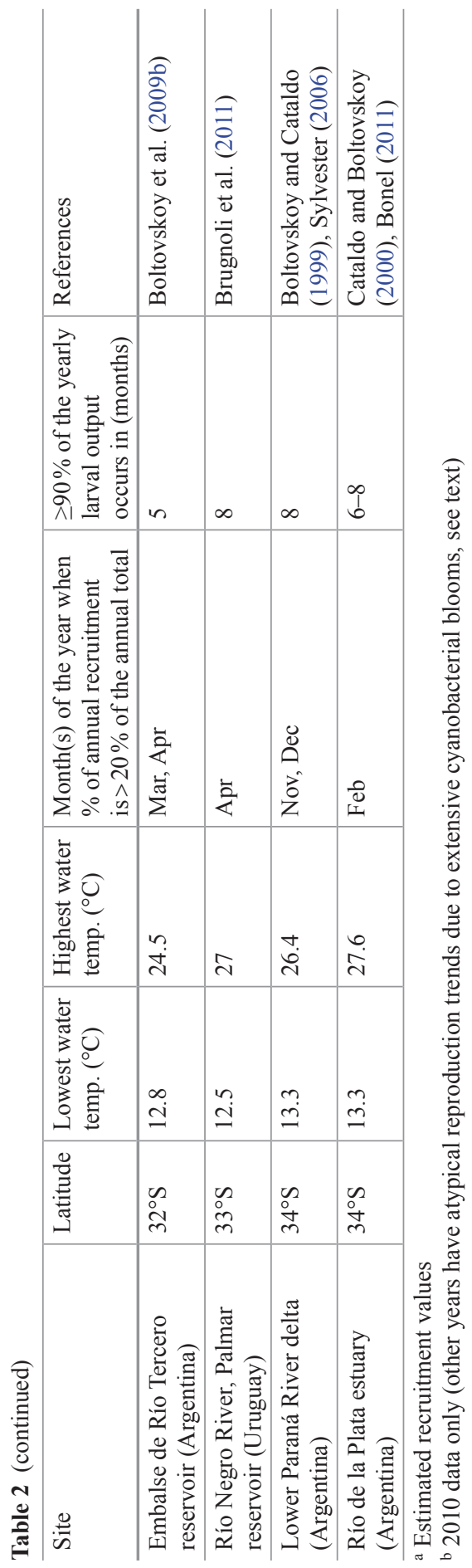




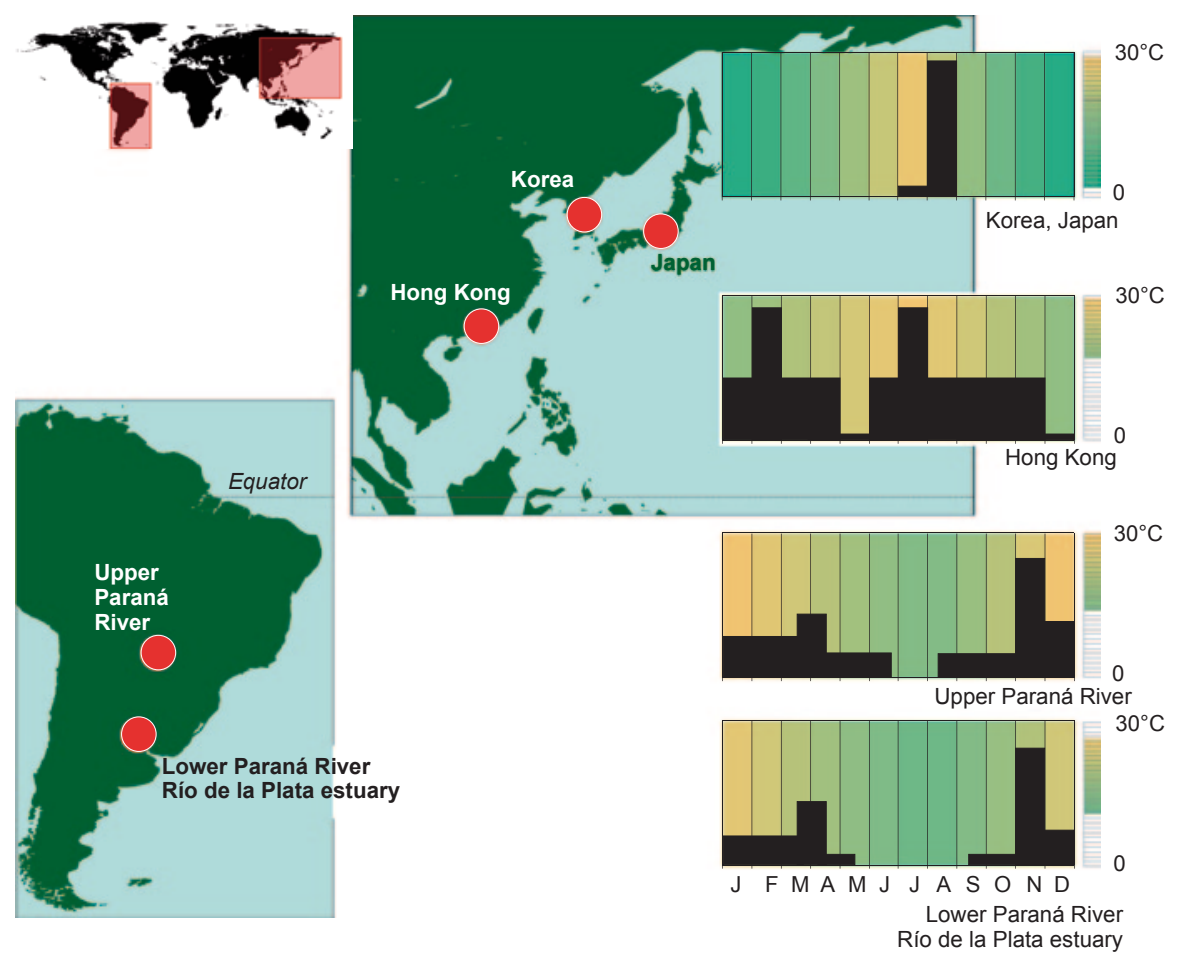

Fig. 10 Proposed relationship between latitude, water temperature, and reproductive activity of Limnoperna fortunei. Histograms indicate relative strength of recruitment throughout the year. Bars next to histogram denote water temperature (see text for explanation)

it extends more than 6-8 months in the latter (Table 2). At similar thermal regimes (around $13-26^{\circ} \mathrm{C}$ ), larvae are present during only 4 months in the Uji River (Japan; Iwasaki and Uryu 1998), and up to 8 months in the Río de la Plata estuary (Table 2). Departures from this temperature-dependent reproduction mode are also evident when comparing several South American sites. For example, in the reservoir Embalse de Río Tercero (Argentina), the reproductively active period is at least 3-4 months shorter than expected from its water temperature span (Table 2). Boltovskoy et al. (2009b) suggested that a lower food supply is possibly responsible for the shorter reproductive period at this waterbody. In the Miranda River (tributary of the Paraguay River), where water temperatures are always above $20^{\circ} \mathrm{C}$, larvae are absent for half of the year (Table 5.1.2), which may be a response to extended anoxic events and/or low calcium concentrations (Oliveira et al. 2011). In Salto Grande reservoir (Uruguay River, Argentina-Uruguay), extensive blooms of toxic cyanobacteria can suppress reproduction almost entirely, regardless of water temperature (Boltovskoy et al. 2013; Figs. 8 and 9).

These results suggest that, in addition to temperature, many factors can play key roles in shaping the reproductive cycle of L. fortunei. Ultimately, however, the reproductive cycle, in coordination with aspects of its overall physiological 
tolerances, determines the success of the species not only in its native environment but also in its introduced ranges. In particular, the short life span of L. fortunei, rapid sexual maturity, and fast growth designate it as an $r$-selected species in contrast to the more long-lived, slow-growing, and similarly freshwater representatives of the Unionidae, which follow $K$-selected life history strategies (Morton 1991).

The heteromyarian, triangular, basally flattened, body form associated with byssal attachment has allowed L. fortunei to exploit the epibenthic niche of both lentic and lotic waters - previously unoccupied by representatives of the Bivalvia. These freshwater habitats were similarly invaded by species of Dreissenidae, notably $D$. polymorpha, and thus provide us a remarkable example of convergent evolution. In both mytiloid and dreissenid cases, however, it is their similar reproductive strategies of fast growth, rapid maturity, high fecundity, broadcast spawning, external fertilization, brief larval lives, and recruitment to established colonies (probably mediated by parental pheromones: Sardiña et al. 2009) that are undoubtedly responsible for the success of them both.

At present, the natural and introduced ranges of both L. fortunei and D. polymorpha do not overlap and although we can but hope that they never do, they most likely inevitably will. In that scenario, it will be fascinating to research the outcome (see Chapter "Parallels and Contrasts Between Limnoperna fortunei and species of Dreissena" in this volume). In the modern world, increasingly, it is the opportunists who are coming to dominate our global ecosystems, and nowhere else is this more obvious than in freshwaters.

Acknowledgments This work was partially financed by grants from the University of Buenos Aires, Argentina (UBA X-020 and 20020100100035) and from the Argentine Agencia Nacional de Promoción Científica y Tecnológica, Argentina (PICT 2007 1968) to DB.

\section{References}

Berger WH, Wefer G (1990) Export production: seasonality and intermittency, and paleoceanographic implications. Palaeogeogr Paleoclimatol Paleoecol 89:245-254

Boltovskoy D, Cataldo D (1999) Population dynamics of Limnoperna fortunei, an invasive fouling mollusc, in the lower Paraná River (Argentina). Biofouling 14:255-263

Boltovskoy D, Karatayev A, Burlakova L, Cataldo D, Karatayev V, Sylvester F, Mariñelarena A (2009a) Significant ecosystem-wide effects of the swiftly spreading invasive freshwater bivalve Limnoperna fortunei. Hydrobiologia 636:271-284

Boltovskoy D, Sylvester F, Otaegui A, Leytes V, Cataldo D (2009b) Environmental modulation of the reproductive activity of the invasive mussel Limnoperna fortunei in South America. Austral Ecol 34:719-730

Boltovskoy D, Correa N, Bordet F, Leites V, Cataldo D (2013) Toxic Microcystis (cyanobacteria) inhibit recruitment of the bloom-enhancing invasive bivalve Limnoperna fortunei. Freshw Biol 58:1968-1981

Bonel N (2011) Demografía experimental de un bivalvo invasor, Limnoperna fortunei (Dunker, 1857), en la cuenca del Plata. PhD Thesis, Universidad Nacional de La Plata (Argentina), pp $1-180$ 
Bonel N, Solari LC, Lorda J (2013) Differences in density, shell allometry and growth between two populations of Limnoperna fortunei (Mytilidae) from the Río de la Plata basin, Argentina. Malacologia 56:43-58

Brugnoli E, Dabezies MJ, Clemente JM, Muniz P (2011) Limnoperna fortunei (Dunker 1857) en el sistema de embalses del Rio Negro, Uruguay. Oecologia Australis 15:576-592

Burlakova LE, Karatayev AY, Padilla DK (2006) Changes in the distribution and abundance of Dreissena polymorpha within lakes through time. Hydrobiologia 571:133-146

Callil CT, Gomes ALT, Soares ACPV (2012) A gametogênese em Limnoperna fortunei (Dunker, 1857). In: Mansur MCD, Santos CP, Pereira D, Padula Paz IC, Leite Zurita ML, Raya Rodriguez MT, Vilar Nehrke M, Aydos Bergonci PE (eds) Moluscos límnicos invasores no Brasil. Biologia, prevenção, controle. Redes Editora, Porto Alegre, pp 111-118

Canzi C, Bortoluzzi L, Rodriguez Fernandez D (2005) Ocorrência e situação atual do mexilhão dourado (Limnoperna fortunei ) no reservatório da central hidrelétrica de Itaipu. In: I Simpósio Brasileiro sobre Espécies Exóticas Invasoras, Brasilia (Brazil)

Cataldo D, Boltovskoy D (2000) Yearly reproductive activity of Limnoperna fortunei (Bivalvia) as inferred from the occurrence of its larvae in the plankton of the lower Paraná River and the Río de la Plata estuary (Argentina). Aquat Ecol 34:307-317

Cataldo D, Boltovskoy D, Hermosa JL, Canzi C (2005) Temperature-dependent larval development rates of Limnoperna fortunei (Bivalvia: Mytilidae). J Molluscan Stud 71:41-46

Cepero E (2003) Control de Limnoperna fortunei. Infestación de plantas potabilizadoras de agua. In: 13 Congreso Argentino de Saneamiento y Medio Ambiente, Buenos Aires (Argentina)

Choi SS, Shin CN (1985) Study on the early development and larvae of Limnoperna fortunei. Korean J Malacol 1:5-12 [In Korean]

Damborenea MC, Penchaszadeh P (2006) Biología reproductiva de Limnoperna fortunei. In: Darrigran G, Damborenea MC (eds) Bio-invasion del mejillón dorado en el continente americano. Editorial de la Universidad de La Plata, La Plata, pp 71-84

Darrigran GA, Damborenea C, Penchaszadeh PE (1998) A case of hermaphroditism in the freshwater invading bivalve Limnoperna fortunei (Dunker, 1857) (Mytilidae) from Río de la Plata, Argentina. Iberus 16:99-104

Darrigran GA, Penchaszadeh PE, Damborenea C (1999) The reproductive cycle of Limnoperna fortunei (Dunker, 1857) (Mytilidae) from a neotropical temperate locality. J Shellfish Res 18:361-365

Darrigran GA, Penchaszadeh PE, Damborenea C, Greco N (2002) Abundance and distribution of golden mussel (Limnoperna fortunei) larvae in a hydroelectric power plant in South America. In: 11th International Conference on Aquatic Invasives Species, Alexandria (USA)

Darrigran GA, Damborenea C, Penchaszadeh PE, Taraborelli C (2003) Reproductive stabilization of Limnoperna fortunei (Bivalvia, Mytilidae) after ten years of invasion in the Americas. J Shellfish Res 22:141-146

Darrigran GA, Damborenea C, Greco N (2007) An evaluation pattern for antimacrofouling procedures: Limnoperna fortunei larvae study in a hydroelectric power plant in South America. Ambio 36:575-579

Ezcurra de Drago I, Montalto L, Oliveros OB (2006) Desarrollo y ecología larval de Limnoperna fortunei. In: Darrigran G, Damborenea C (eds) Bio-invasión del mejillón dorado en el continente americano. Editorial de la Universidad de La Plata, La Plata, pp 85-93

Garton DW, Haag WR (1993) Seasonal reproductive cycles and settlement patterns of Dreissena polymorpha in western Lake Erie. In: Nalepa TF, Schloesser DW (eds) Zebra mussels: biology, impacts, and control. Lewis Publishers, Boca Raton, pp 111-128

Gist DH, Miller MC, Brence WA (1997) Annual reproductive cycle of the zebra mussel in the Ohio River: a comparison with Lake Erie. Archiv Hydrobiologie-Beiheft Ergebnisse der Limnologie 138:365-379

Hamada M (2011) Relationship between water temperature and period of occurrence and attachment in planktonic larvae of golden mussel Limnoperna fortunei, in the Yahagi River. Rep of Yahagi River Inst 15:45-54 [In Japanese] 
Iwasaki K, Uryu Y (1998) Life cycle of a freshwater Mytilid mussel, Limnoperna fortunei, in Uji River, Kyoto. Venus (Japanese J Malacol) 57:105-113

Karatayev AY, Boltovskoy D, Padilla DK, Burlakova LE (2007) The invasive bivalves Dreissena polymorpha and Limnoperna fortunei : parallels, contrasts, potential spread and invasion impacts. J Shellfish Res 26:205-213

Karatayev AY, Burlakova LE, Karatayev VA, Boltovskoy D (2010) Limnoperna fortunei versus Dreissena polymorpha : population densities and benthic community impacts of two invasive freshwater bivalves. J Shellfish Res 29:975-984

Lewandowski K (1982a) On the variable numbers of the mollusc Dreissena polymorpha (Pall.). Wiad Ekologiczne 28:141-154

Lewandowski K (1982b) The role of early developmental stages in the dynamics of Dreissena polymorpha (Pall.) (Bivalvia) populations in lakes. II. Settling of larvae and the dynamics of number of settled individuals. Ekologia Polska 30:223-286

Magara Y, Matsui Y, Goto Y, Yuasa A (2001) Invasion of the non-indigenous nuisance mussel, Limnoperna fortunei, into water supply facilities in Japan. J Water Supply: Res Technol—Aqua $50: 113-124$

Maroñas ME, Darrigran GA, Sendra ED, Breckon G (2003) Shell growth of the golden mussel Limnoperna fortunei (Dunker 1857) (Mytilidae) in the Rio de la Plata, Argentina. Hydrobiologia 495:41-45

Mata FAR (2011) Abundância e distribuição temporal de Limnoperna fortunei Dunker, 1857 (Mollusca, Bivalvia) e os impactos da incrustação em usinas geradoras de energia elétrica. MSc Thesis, Universidade Federal de Ouro Preto (Brazil), pp 1-91

McMahon RF, Bogan AE (2001) Mollusca: Bivalvia. In: Thorn JH, Covich AP (eds) Ecology and classification of North American freshwater invertebrates. Academic Press, San Diego, pp 331-429

Morton B (1969) Studies on the biology of Dreissena polymorpha Pall. (III). Population dynamics. Proc Malacol Soc Lond 38:471-182

Morton B (1973) Some aspects of the biology and functional morphology of the organs of feeding and digestion of Limnoperna fortunei (Dunker) (Bivalvia: Mytilacea). Malacologia 12:265-281

Morton B (1977) The population dynamics of Limnoperna fortunei (Dunker 1857) (Bivalvia: Mytilacea) in Plover Cove Reservoir, Hong Kong. Malacologia 16:165-182

Morton B (1982) The reproductive cycle in Limnoperna fortunei (Dunker, 1857) (Bivalvia: Mytilidae) fouling Hong Kong's raw water sypply system. Oceanologia Limnologia Sinica 13:312-324

Morton B (1991) Do the Bivalvia demonstrate environment-specific sexual strategies? A Hong Kong model. J Zool Lond 223:131-142

Nakano D, Kobayashi T, Sakaguchi I (2010a) Differences in larval dynamics of golden mussel Limnoperna fortunei between dam reservoirs with and without an aeration system. Landsc Ecol Eng 6:53-60

Nakano D, Kobayashi T, Sakaguchi I (2010b) Predation and depth effects on abundance and size distribution of an invasive bivalve, the golden mussel Limnoperna fortunei, in a dam reservoir. Limnology 11:259-266

Nalepa TF, Wojcik JA, Fanslow DL, Lang GA (1995) Initial colonization of the zebra mussel (Dreissena polymorpha) in Saginaw Bay, Lake Huron: population recruitment, density, and size structure. J Great Lakes Res 21:417-434

Nichols SJ (1993) Spawning of zebra mussels (Dreissena polymorpha) and rearing of veliger under laboratory conditions. In: Nalepa TF, Schloesser DW (eds) Zebra mussels: biology, impacts, and control. Lewis Publishers, Boca Raton, pp 315-329

Nichols SJ (1996) Variations in the reproductive cycle of Dreissena polymorpha in Europe, Russia, and North America. Am Zool 36:311-325

Olive PJW (2002) Reproduction and life cycles in invertebrates. In: Tickle C (ed) Encyclopaedia of life sciences. Wiley, New York, pp 1-9 
Oliveira MD, Calheiros DF, Jacobi CM, Hamilton SK (2011) Abiotic factors controlling the establishment and abundance of the invasive golden mussel Limnoperna fortunei. Biol Invasions 13:717-729

Pestana D, Pie MR, Ostrensky A, Boeger WA, Andreoli C, Franceschi F, Lagos P (2008) Seasonal variation in larval density of Limnoperna fortunei (Bivalvia, Mytilidae) in the Iguaçu and Paraná rivers, in the region of Foz do Iguaçu, Paraná, Southern Brazil. Braz Arch Biol Technol 51:607-612

Rojas Molina F (2010) Efectos del molusco invasor Limnoperna fortunei (Dunker) sobre el zooplancton del paraná medio. PhD Thesis, Universidad de Buenos Aires (Argentina), pp 1-205

Santos CP, Mansur MCD, Wurdig Nl (2008) Variaçoes no comprimento dos individuos de uma populacão do mexilhão dourado, Limnoperna fortunei (Mollusca: Bivalvia: Mytilidae), ao longo do ano, na Praia do Veludo, Lago Guaiba, Rio Grande do Sul, Brasil. Braz J Biol 25:389-396

Sardiña P, Cataldo D, Boltovskoy D (2009) Effects of conspecifics on settling juveniles of the invasive golden mussel, Limnoperna fortunei. Aquat Sci 71:479-486

Smirnova NF, Biochino GI, Vinogradov GA (1993) Some aspects of the zebra mussel (Dreissena polymorpha ) in the former European USSR with morphological comparisons to Lake Erie. In: Nalepa TF, Schloesser D (eds) Zebra mussels: biology, impacts, and control. Lewis Publishers, Boca Raton, pp 217-226

Smit H, bij de Vaate A, Reeders HH, van Nes EH, Noordhuis R (1993) Colonization, ecology, and positive aspects of zebra mussels (Dreissena polymorpha) in The Netherlands. In: Nalepa TF, Schloesser D (eds) Zebra mussels: biology, impacts, and control. Lewis Publishers, Boca Raton, pp 55-77

Soares MCS, Huszar VLM, Miranda MN, Mello MM, Roland F, Lürling M (2013) Cyanobacterial dominance in Brazil: distribution and environmental preferences. Hydrobiologia 717:1-12

Stanczykowska A (1977) Ecology of Dreissena polymorpha (Pall.) (Bivalvia) in lakes. Polskie Archiwum Hydrobiologii 24:461-530

Strayer DL, Malcom HM (2006) Long-term demography of a zebra mussel (Dreissena polymorpha ) population. Freshw Biol 51:117-130

Sylvester F (2006) Biología alimentaria y ecología del molusco invasor Limnoperna fortunei (Mytilidae) en el Paraná inferior y Río de la Plata. PhD Thesis, Universidad de Buenos Aires (Argentina), pp 1-160

Tanaka H, Deno T, Kondo T (2004) Effect of gasterostome trematode infection on growth and reproduction in Limnoperna fortunei (Bivalvia: Mytilidae). Memoirs of Osaka Kyoiku University, Series III. Nat Sci Appl Sci 53:1-7

Uliana ER, Callil CT (2006) Avaliação do ciclo sexual do mexilhão dourado, Limnoperna fortunei (Dunker, 1857), no Rio Paraguai, Porto Esperança-MS. BS Thesis, Universidade Federal de Mato Grosso (Brazil), pp 1-33

Zanella O, Marenda LD (2002) Ocorrência de Limnoperna fortunei na Central Hidrelétrica de Itaipu. In: V Congresso Latinoamericano de Malacologia, São Paulo (Brazil) 